\title{
Rural women's farmers access to productive resources: the moderating effect of culture among Nupe and Yoruba in Nigeria
}

\author{
Adebola Adewumi Ajadi ${ }^{1}$, Oladimeji Idowu Oladele ${ }^{2 *}$, Koichi Ikegami $^{1}$ and Tadasu Tsuruta ${ }^{1}$
}

\begin{abstract}
Background: This paper analyzes ownership and control of productive resources by gender as determined by culture. This is premised on the fact that past researchers have isolated gender and productive resources on one hand and gender and culture on the other. In this paper, the novelty is the exploration of the interplay among culture, gender and productive resources. Using a descriptive quantitative research design, a simple random sampling was used to select 100 households from a sampling frame of 200 households generated through house listing in three villages from Patigi Local Government Area of Kwara State. Data were collected with a structured questionnaire covering ownership, and decision making on selected productive resources and analyzed using Frequency counts, percentages and Chi-square test statistics based on the fact that the variables are categorical. Gender and ownership as well as decision making were cross-tabulated and then layered with culture as a third variable.
\end{abstract}

Results: The results were disaggregated along Nupe and Yoruba culture as well as along gender lines for the selected productive resources covered in this paper. Men predominate in ownership of productive resources among Yoruba than Nupe culture. Women from Nupe culture had higher distribution of ownership in the productive resources than men particularly land, small livestock and non-mechanized farm equipment. The results further show higher proportion of ownership of productive resources among men in Yoruba culture. Women in Nupe culture had greater proportion of ownership of productive resources than Yoruba women. Males make decision to sell all productive resources except small livestock and also make decision in almost all the farming activities listed except when and who will take crop to the market in both Nupe and Yoruba cultures.

Conclusion: Culture has a stronger influence on women's access and control of productive resources than the mere biological differentiation of gender into male and female. There is a strong cultural influence among Nupe and Yoruba women as a result of the interplay of gender, ownership and decision making and culture on selected productive resources.

Keywords: Productive resources, Gender, Nupe, Culture, Yoruba, Gender

\section{Background}

Women are the backbone of the development of rural and national economies as they represent $43 \%$ of the global agricultural labor force and in Africa, $80 \%$ of the agricultural production comes from small farmers, who

\footnotetext{
*Correspondence: Oladele20002001@yahoo.com

2 Department of Agricultural Economics and Extension, Mafikeng Campus, North-West University, Private Bag X 2046, Mmabatho 2735, South Africa

Full list of author information is available at the end of the article
}

are mostly rural women but they do not have access and control over all land and productive resources [1]. Cultural issues have had significant influence in rural household economies, which over the years depend strongly on agriculture. Culture consists of a whole complex of distinctive spiritual, material and intellectual features that characterize a society or social group. It includes not only the arts and letters, but also modes of life, the fundamental rights of the human being, value systems, traditions and beliefs [2]. Cultural factors refer to a set of beliefs, 
moral values, traditions, language and laws held by a nation, a community or other defined group. Issues associated with culture are deeply embedded in the tradition of the people which govern their indigenous knowledge system with wide applications in their livelihood pursuits [3]. Ogwumike [4] stated that culture and religion moderate the role and livelihood activities of women in most parts of Nigeria as well as their access to land and other productive resources. Culture therefore structures and determines the way social institutions shape life as well as cultivated and imposed behavior communally transmitted from one generation to another. Due to the fact that development involves changing cultural attitudes and institutions, cultural approach is one of the determinants of the success of development strategies in many parts of Africa. Food and Agriculture Organisation of the United Nations (FAO) [5] reported that social customs limit women's participation in decision-making processes and their exposure to economic opportunities that arise, thus increasing the level of inequality vis-à-vis their partners.

Cultural and institutional factors often limit women's access to land ownership, labor, and capital. Access to land is often restricted to usufruct rights; women cannot provide collateral for credit because they may not have legal ownership of tangible assets. A study of the evolution of land tenure institutions in western Ghana shows that the gender implications of land ownership are complex and subject to change over time [6]. In Nigeria, women constitute a substantial proportion of the country's farming population and provide about $60-80 \%$ of the rural labor input, performing multiple roles for the survival of their families [7]. Many other literature have shown various contributions of women to agricultural production in Nigeria. However, women's access to productive resources is limited; it seems that they seldom have the right to decide whether to sell some important assets of their family, or, what kind of crops they grow on farms. Damisa and Yohanna [8] revealed that, though female farmers are heavily involved in agriculture, the level of their participation in farm management decision making such as purchases and sales of farmland or farming equipment is quite low. The role of women in decision-making process in Nigerian agriculture should be further explored. Stamp [9] indicated that the ideology and practice of kinship and kin relations as the superstructure of production relations is central to the shaping of production relations, economic work and the fulfillment of kin obligations were inseparable both conceptually and in practice. Ogwumike [4] noted that discrimination, a situation where unequal opportunities are given to some people to participate in the production process on the basis of gender, age and ethnic considerations has impeded livelihood activities a great deal particularly among women.

Thamaga-Chitja and Morojele [10] stated that the patriarchal nature of rural discourse regards women as minors under the authority of men as heads of household, which denies women to have direct access to agriculturally productive resources. Oladele [11] stated that language as a cultural element is one of the main factors influencing access to agricultural information disseminated through radio and television in Nigeria. The language of radio and television broadcasts in an ethnically diverse countries in Africa may increase agricultural information uptake by farmers, compared to use of official languages that are not understood by most farmers. Although language is not peculiar to women, the magnitude of the limiting effect of such exclusion could be enormous when women experience that in many other productive resources. Culture is an important variable which has effect on the economic activities such as farming; thus, the behavioral pattern and meaning people ascribe to culture requires the knowledge or their history and belief system [12].

Rural settlements in Nigeria are either dispersed, clustered or lined depending on the historical factors underlying its founding, geographical and social factors as well as the nature of the prevailing agricultural economy [13]. Settlement patterns refer to the manner that a population distributes itself within the geographical space it occupies. With rural people, this has to do with how the people locate themselves in relation to their farms. Village organization also refers to the patterns of social interaction, ordering and governance of rural settlements. These affect the strategy that a change agent may employ to effectively reach his change targets. Clustered settlements are common among the Yoruba, Hausa and Nupe, whereas scattered settlements prevail in the Ibo, Ibibio and Tiv areas. Line settlements are found along river courses and new roads [13].

In Nigeria, Nupe is one of the minor ethnic groups in Nigeria and are about 1,245,000 in population, and their location along the Niger River has always made them important in riverine trade and also rice production. The landscape of Nupe communities is characterized with undulating land formations of hills, rivers, flood plains and highlands. There is always a seasonal change of landscape character especially during the raining seasons when river Niger and river Kaduna overflow their bounds, which turns highland open bush into swamps. The crops cultivated on the highlands of Nupe communities are millets, yam, cassava, maize and groundnut; sugarcane and rice are cultivated on the flood plains [14]. As such the landscape types of either flood plain or 
highlands have historically formed the basis on the specialty of crops cultivated by various Nupe communities. The Nupe people are constituted in various communities with different landscape and occupation such that the landscape type reflects the different occupation of the communities [12]. Furthermore, the Nupe calendar is also naturalistic as they live and really on environmental conditions of dry season, rain, cold and hot season to tell time. All the foregoing gives an insight into the multifaceted nature and rich cultural landscape of Nupe community as a whole.

In Nupe culture, the pattern of control of land and land-related activities can be summarized in a three-layered structure. The territory of a community as a whole is governed by the chief, normally the eldest man among lineal descendants of the first settler. The chief's power is, however, restricted to allocation of farmland and management of vacant land, while each individual, group, or family can exercise exclusive right on the land on their own farming. Another layer implies landlords as a remnant of feudalistic system of the Nupe kingdom [12]. It consists of absentee or sometimes resident landlords: the former are the privileged class of town Fulani and the latter, or rather farmer Fulani, probably originated from subordinates or slaves. Finally, the Emir dominates the traditional value system that still regulates the people's daily life. His power, however, does not reach every corner of the land, but is limited to the people. Therefore, a current Emir can directly control the estates but not other lands belonging to various title holders forming noble class [14]. The extended family system of the Nupe is accompanied with patrilineal, patrilocal, and Islamic polygyny. Though it can be categorized to exogamy, intermarriage is prohibited only among the same extended family members. Marriage including deuterogamy inside a community that consists of several extended families often occurs, which makes the kinship structure complicated. The eldest man becomes the head of a consanguine family (emi tsuo) and controls his family that involves plural conjugal or polygynic families [13].

The Yoruba people occupy the south-western part of Nigeria mainly and are principally famers and traders by occupation. Polygamy is very common and so Yoruba families are large and kinship bonds are very strong which is patrilineal and patrilocal family structure. The oldest male in the compound is recognized as its head who allocates land for farming, settles disputes in the compound and acts as the political head of the compound being directly responsible to the town or village authority for everything in the compound. The typical Yoruba village or town is divided into quarters or wards and each ward is in turn, made up of a number of compounds. The first compound by settlement may assume leadership of the ward. Each compound has a Bale who is responsible for maintaining peace and order in his compound. The Bale is accountable to the Oba of the town for everything concerning the compound. The founder of settlements and their descendants exercised proprietary rights over the estates of the settlement and receive tributes and other services from those farming on such lands or establishing branch or tributary settlements on them [13]. Land tenure refers to the rights to hold, use and possess the natural resources found in the land profile which embraces three basic components including ownership, transfer and use. Ownership entails the right to have and retain land for certain uses. Ownership creates access to occupation, use, lease and redemption of a piece of land. Use refers to the purpose for which land is put, while transfer entails the conveyance of rights over a piece of land from one person or group to another on a temporary or permanent basis. In principle, the right to land use, ownership or transfer in Yorubaland is held by groups ranging from the elementary family, the lineage, the ward, the village or town. The Oba holds all land in trust for the people within his domains [13].

The peculiar family organizations in Nupe and Yoruba point out the importance of cultural organization of the rural families to reach and work with them successfully. Tradition, culture and social circumstances have also vested authority and dominance in the family on either the man or the woman. Where the man (father) is dominant, the family is described as patriarchal or patricentric $[12,13]$. This may take the form of the husband in the immediate nuclear family exercising authority or the authority being vested in the eldest male in the extended family. Authority here entails family decision making on important issues, allocation of farm plots, administration at the family shrines and the exercise of other forms of political authority over family members [13].

Access to productive resources is a crucial factor in rural development all over the world. Rural households negotiate their livelihoods by obtaining access to productive resources, which leads to enhanced family well-being [15]. Productive resources can be both tangible, as in capital, land, labor and raw materials, and intangible, such as knowledge, ideas, and market. Access to such resources is also a major issue in the discourse of gender empowerment, especially in developing countries. Okonya and Kroschel [16] reported that gender differences in access and use of selected productive resources exist among sweet potato farmers in Uganda.

World Bank [17] stated that women supply about $60-80 \%$ of agricultural labor force in Nigeria, and produce two-thirds of food crops consumed. Despite the significant roles women play in agriculture and food security irrespective of culture, they continue to have a poorer 
command over a range of productive resources, including education, land, information, and financial resources [18]. Furthermore, economic, extension and other public institutions in most developing countries are genderbiased, in that the needs of women are often ignored or overlooked [19]. As rural women have been contributing greatly to agricultural production and food security in developing countries, empowering rural women through improved access to key productive resources and agricultural services is one of the possible options to alleviate rural poverty. Improving access of rural female farmers to productive resources such as land, water and finance could play a significant role in enhancing female farmers' productivity and food security. In addition, female farmers' access to agricultural services such as credit, extension and rural institutions enables them to manage their environmental and socio-economic challenges in agriculture on a sustainable basis [20].

Reducing the gender asset, gap has been shown to have positive outcomes, not only for women themselves but for households. Women's ownership of assets has been shown to increase their bargaining power, their role in household decision making and expenditures on children's education and health [21]. The gender asset gap is also a critical indicator of women's empowerment. FAO [22] stated that gender differences in assets are generally interlinked, for example, when female farmers have lower levels of technology this is due to their having less access to land, less access to labor and less access to extension services which implies a spiraling effect.

Several studies $[17,23]$ have been conducted to establish the constraints facing women farmers and many variables have been isolated in literature through qualitative and statistical inferences stating that cultural factors affect women access and control on productive resources. In this paper, the novelty is the exploration of the interplay among culture, gender and productive resources. The focus is how much of access and control of productive resources by gender is determined by culture. The relationships between gender and control of productive resources were moderated with the culture as a variable. The moderating effect of culture brings to fore how much of women inaccessibility and lack of control of productive resources is due to gender bias or cultural interference. This paper, therefore, attempts to examine rural women's access to productive resources in Nupe and Yoruba cultures of Nigeria, from the viewpoint of their decision making on family assets and farm management. Focusing on important productive resources such as farmland and livestock, this paper analyzes ownership and control of these assets from the viewpoint of gender, as well as decision making on farming activities including both subsistence agriculture and market-oriented agriculture.
This analysis may well highlight the uniqueness of gender issues related with decision making against conventional understandings.

\section{Methods}

The research was conducted in Nupe land in central Nigeria. The Nupe people live along the valleys of the Niger and Kaduna rivers in central Nigeria, and in the adjacent savannah. The study was conducted in Patigi Local Government Area of Kwara State, which was selected due to the largest concentration of rice farmers along river Niger in all the areas of Nupeland. The Area has a total land area of $2743 \mathrm{~km}^{2}$ and a population of about 110,852 [24]. The climate is characterized by rainy and dry seasons. The rainy season begins from early April and ends in October and the dry season continues from the end of November to March [24]. Descriptive quantitative research design was used in this study and the population of study was Nupe and Yoruba farmers in Bissan, Sakpefu and Lade in Patigi Local Government Area of Kwara State. To generate a sampling frame, the researchers conducted house listing from three villages, namely Bissan (50 households), Sakpefu (100 households), Lade (50 households) villages to obtain a total of 200 households. After that, 100 farmers were selected out of 200 households by a simple random sampling using the drawing from the hat method. The simple random sampling gives equal chance to every household to be selected. A structured questionnaire covering ownership, and decision making on selected productive resources such as agricultural land (pieces, plots), large livestock (cattle), small livestock (goats, pigs, sheep), chicken, ducks, turkeys, pigeons and farm equipment (non-mechanized) was used to collect data in February 2013. Trained enumerators who understand Nupe language were used for the face-to-face interviews survey under close supervision by one of the researchers. Ownership, gender of owners, decision makers and gender of decision makers were measured on nominal level with a score of one for female and two for male. Culture as the moderating variable was measured as a categorical variable with labels as Nupe $=1$ and Yoruba $=2$. Data were collected after explaining the objective of the research to respondents and their consent was sought, with the assurance of confidentiality and no form of deception on the benefits of the research to the respondents. Data were analyzed as a reference group and no individual identifiers were included in the data or the results. Ethics approval was granted by the committee of the environmental policy laboratory of Kinki University Japan. Data were analyzed using frequency counts, percentages and Chi-square test statistics based on the fact that the variables are categorical. Gender and ownership as well as decision making 
were cross-tabulated and then layered with culture as a third variable.

\section{Results and discussions}

The results were disaggregated along Nupe and Yoruba culture as well as along gender lines for the selected productive resources covered in this paper. Table 1 presents the results on the ownership of productive resources by gender across cultures. Men predominate in ownership of productive resources among Yoruba than Nupe culture. Women from Nupe culture had higher distribution of ownership in the productive resources than men particularly land, small livestock and non-mechanized farm equipment. This may be due to the fact that Nupe men have higher migratory tendencies than Yoruba men. Malefemale differences still exist on access, control and decision making on productive resources. This is often attributed to the cultural differentiated reasons which permeate the behavioral disposition in relation to productive resources. In South Africa, women's access to land is indirect, meaning that it is mediated through a man: their father, brother, husband or even son. It is usual for women in these societies to have limited or no decision making power over land, other than a small garden from which they are expected to produce subsistence crops, the proceeds of which they may exercise control over [25]. The literature also points to structural tensions between the recognition of traditional authorities and the empowerment of women in rural areas. In South Africa, local authorities, who have considerable influence in local governments, may resist granting women access to land or allowing women to participate in decision-making bodies. Fafchamps and Quisumbing [26] in a study carried out in Ethiopia found that husbands generally keep the land upon the dissolution of a marriage. Although female household heads may have access to land, they frequently lack other productive resources, such as labor, oxen, and credit, making it difficult for them to obtain inputs. Sole cattle ownership by women is not common in Ethiopia, although joint ownership by spouses is found in many regions.
Oluka, Owoyesigire, Esenu and Sssewannyana [27] found in the Ugandan districts of Kaberamaido and Katakwi that small stock, especially goats and chickens, are owned by women, children and the landless while cattle, of higher economic value, are owned by men. Swiss Agency for Development and Cooperation [28] noted that historically, in most cultures, women's access to land involved right of use, but not ownership and that when common land is converted into state ownership and then to private land, women often lose their traditional rights and are often not considered when new laws are introduced. FAO [22] stated that gender influences kind of technology available used by women farmers as in some cultures, women do not traditionally use draught oxen and this can severely curtail their access to timely farm power. Swiss Agency for Development and Cooperation [28] stated that the cultural perception implies that with marriage all the belongings of the women, including herself, revert to the ownership of men such that in Niger, where livestock is often a part of the dowry, but the control over the animals after marriage belongs to the man. FAO [22] stated that gender analysis of ownership and use of mechanization-tools and other farming equipment are rare and that male-headed households in Ghana and Nigeria show much wider use of mechanization-tools and other farming equipment than their female counterparts. The complementarities and synergetic aspects of agricultural inputs were stressed by the fact that gender differences in utilization of farm equipment may have further implications as farmers with more land and tools are likely to adopt other technologies.

The percentages of resources owned by women can be misleading if treated in isolation from the actual numbers owned. Table 2 shows the proportion of productive resources owned by gender across cultures. The table shows higher proportion of ownership of productive resources among men in Yoruba culture. Women in Nupe culture had greater proportion of ownership of productive resources than Yoruba women. International Livestock Research Institute/International Development

Table 1 Ownership of productive resources by gender across cultures

\begin{tabular}{|c|c|c|c|c|c|c|c|c|c|c|}
\hline \multirow[t]{3}{*}{ Productive capital } & \multicolumn{5}{|l|}{ Nupe } & \multicolumn{5}{|l|}{ Yoruba } \\
\hline & \multicolumn{2}{|l|}{ Male } & \multicolumn{2}{|l|}{ Female } & \multirow[t]{2}{*}{ No response } & \multicolumn{2}{|l|}{ Male } & \multicolumn{2}{|l|}{ Female } & \multirow[t]{2}{*}{ No response } \\
\hline & Yes & No & Yes & No & & Yes & No & Yes & No & \\
\hline Agricultural land (pieces, plots) & $20(40)$ & $3(6)$ & $23(46)$ & $1(2)$ & $3(6)$ & $25(50)$ & $5(10)$ & $18(36)$ & $1(2)$ & $1(2)$ \\
\hline Large livestock (cattle) & $18(36)$ & $4(8)$ & $19(38)$ & $5(10)$ & $4(8)$ & $20(40)$ & $8(16)$ & $14(28)$ & $5(10)$ & $3(6)$ \\
\hline Small livestock (goats, pigs, sheep) & $22(44)$ & $1(2)$ & $23(46)$ & $1(2)$ & $3(6)$ & $25(50)$ & $3(6)$ & $14(28)$ & $4(8)$ & $4(8)$ \\
\hline Chicken, ducks, turkeys, pigeons & $22(44)$ & $1(2)$ & $23(46)$ & $1(2)$ & $3(6)$ & $27(54)$ & $3(6)$ & $12(24)$ & $5(10)$ & $3(6)$ \\
\hline Farm equipment (non-mechanized) & $16(32)$ & $5(10)$ & $19(38)$ & $5(10)$ & $5(10)$ & $26(52)$ & $4(8)$ & $14(28)$ & $5(10)$ & $1(2)$ \\
\hline
\end{tabular}


Table 2 Proportion of productive resources owned by gender across cultures

\begin{tabular}{|c|c|c|c|c|c|c|c|c|c|c|}
\hline \multirow[t]{3}{*}{ Productive capital } & \multicolumn{5}{|l|}{ Nupe } & \multicolumn{5}{|l|}{ Yoruba } \\
\hline & \multicolumn{2}{|l|}{ Male } & \multicolumn{2}{|l|}{ Female } & \multirow[t]{2}{*}{ No response } & \multicolumn{2}{|l|}{ Male } & \multicolumn{2}{|l|}{ Female } & \multirow[t]{2}{*}{ No response } \\
\hline & $<10$ & $>10$ & $<10$ & $>10$ & & $<10$ & $>10$ & $<10$ & $>10$ & \\
\hline Agricultural land (pieces, plots) & $18(36)$ & $0(0)$ & $22(44)$ & $0(0)$ & $10(20)$ & $19(38)$ & $6(12)$ & $16(32)$ & $2(4)$ & $7(14)$ \\
\hline Large livestock (cattle) & $13(36)$ & $2(4)$ & $14(28)$ & $4(4)$ & $7(14)$ & $17(34)$ & $2(4)$ & $10(20)$ & $14(28)$ & $17(34)$ \\
\hline Small livestock (goats, pigs, sheep) & $5(10)$ & $13(26)$ & $9(18)$ & $13(26)$ & $10(10)$ & $17(34)$ & $4(8)$ & $9(18)$ & $4(8)$ & $16(32)$ \\
\hline Chicken, ducks, turkeys, pigeons & $3(6)$ & $16(32)$ & $6(12)$ & $16(32)$ & $9(18)$ & $17(34)$ & $6(12)$ & $6(12)$ & $5(10)$ & $16(32)$ \\
\hline Farm equipment (non-mechanized) & $4(8)$ & $4(8)$ & $10(20)$ & $3(6)$ & $29(58)$ & $16(32)$ & $5(10)$ & $13(26)$ & $2(4)$ & $14(28)$ \\
\hline
\end{tabular}

Research Centre (ILRI/IDRC) [29] reported that the proportion of livestock owned by women in Kenya, Tanzania and Mozambique and the average numbers they own are much less than that owned by men. Similarly, ILRI/ IDRC [29] reported that in Kenya, men owned 10 times more cattle than women, while in Tanzania men owned 18 times more cattle than women but in Mozambique women owned 0.8 head for every one head of cattle that men owned.

The concept of ownership cannot be taken in isolation from decision making particularly with respect to women-owned assets, it is essential to establish whether they can sell, give out and slaughter, and whether they can make the decisions independently or have to consult other members of the household, especially their husbands. Table 3 reveals the decision making on sales of productive resources by gender across cultures. Males dominate the possession of all the productive capital listed. This may be due to the fact that males are culturally believed to be in charge of these productive resources. On the decision to sell, however, 62 and $74 \%$ of the female respondents make decision to sell small livestock and poultry, respectively, while decision to sell all other productive capital is made by male. On small livestock and poultry, the percentage of female on decision making is quite higher than percentage of male among the Nupes. Among the Yorubas, the decision to sell, unlike Nupe female respondents who make decision to sell small livestock and poultry, Yoruba female respondents make decision to sell only small livestock while decision to sell all other productive capital is made by male. This shows that male still has the possession and control as to the decision to be made on most productive resources. In the case of large livestock, the trend is the same with majority of decision makers on large livestock being male. This is in line with Adereti [30], which shows that women in Osun state of Nigeria do not have absolute control over most of the productive resources such as land, however, Ibrahim et al. [31] show that rural women in Nasarawa state of Nigeria have better access to land, this shows that cultural difference still affect women access to productive resources.

Low participation in decision making is a typical aspect of gender inequality. In general, women farmers in Africa are considered to have been facing severe handicaps [32]. The land ownership, access to other productive resources and the organization of agricultural production are influenced by cultural practices and traditions. For example, rules of land inheritance (by lineage, gender and/or other culturally determined characteristics) are core determinants of effective access to land. Cultural aspects are thus of central importance for the understanding and development of appropriate interventions in agriculture, food security and rural development. Fafchamps and Quisumbing [28] indicated that control over the sale of and proceeds from livestock and livestock products is generally gender differentiated, with women tending to market small livestock and poultry, dairy products, and eggs.

Table 3 Decision making on sales of productive resources by gender across cultures

\begin{tabular}{|c|c|c|c|c|c|c|}
\hline \multirow[t]{2}{*}{ Productive capital } & \multicolumn{3}{|l|}{ Nupe } & \multicolumn{3}{|l|}{ Yoruba } \\
\hline & Female & Male & No response & Female & Male & No response \\
\hline Agricultural land (pieces, plots) & $2(4)$ & $15(30)$ & $33(66)$ & $5(10)$ & $28(56)$ & $17(34)$ \\
\hline Large livestock (oxen, cattle) & $5(10)$ & $32(64)$ & $13(26)$ & $10(20)$ & $26(52)$ & $14(28)$ \\
\hline Small livestock (goat, pigs, sheep) & $31(62)$ & $12(24)$ & $7(14)$ & $19(38)$ & $16(32)$ & $15(30)$ \\
\hline Chicken, ducks, turkeys, pigeons & $37(74)$ & $6(12)$ & $7(14)$ & $20(40)$ & $23(46)$ & $7(14)$ \\
\hline Farm equipment (non-mechanized) & $9(18)$ & $6(12)$ & $35(70)$ & $11(22)$ & $26(52)$ & $13(26)$ \\
\hline
\end{tabular}


The sale of cattle and other large livestock is for the most part in the male domain. Oluka, Owoyesigire, Esenu and Sssewannyana [27] reported that though women have the same authority as men to dispose of their goats, and more decision-making powers over poultry, men dominated on decisions to dispose or sell cattle.

International Livestock Research Institute/International Development Research Centre [29] reported that in Kenya less than $50 \%$ of women could sell their local and improved chickens without consulting their husbands while for larger livestock, only 8.8, 13.8 and $10.0 \%$ of women could sell their dairy cattle, sheep and goats, respectively, without consulting their husbands. Conversely, in Kenya, 43.1, 36.2 and $30 \%$ of women indicated that their husbands could sell their dairy cattle, sheep, goats and pigs, respectively, without having to consult them.

Table 4 shows decision making on farming activities by gender across cultures, male makes decision in almost all the farming activities listed except crop marketing with 62 and $46 \%$, respectively, among Nupe and Yoruba. This may be as a result of the perception that marketing of agricultural produce is the work of women and so the responsibility of taking the crop to the market is left for the women. Fafchamps and Quisumbing [27] noted that gender division of agricultural activities has constrained women's access to extension services. Until recently, horticultural production and the raising of poultry and small ruminants were considered "home economics", excluding women from other agricultural extension advice, training, and credit. Conversely, decision making on farming activities revealed that male predominates in all activities except market-related activities.

Table 5 presents the results of the Chi-square on differences between gender, ownership, decision making and culture on selected productive resources among women of Nupe and Yoruba in Nigeria. Gender and ownership as well as decision making were cross-tabulated and then layered with culture as a third variable. From a list of 15 variables tested, only six show significant relationship which shows a strong cultural influence among Nupe and Yoruba women. These are boldface fonts in Table 5 . The results affirm that ownership of productive resources is strongly influenced by culture for land, large livestock, small livestock and farm equipment. This can be extended to the fact that once ownership is claimed or retained by men the decision and control also rests with them. Oluka, Owoyesigire, Esenu and Sssewannyana [27] found in the Ugandan districts of Kaberamaido and Katakwi that livestock production is culturally male dominated, where men own a disproportionately large number of livestock, especially cattle, while women, who provide the main source of labor for all livestock production activities, as well as being the custodians of food security and family livelihoods, are denigrated to ownership of small stock only, with minimal benefits from livestock production accruing to them. Swiss Agency for Development and Cooperation [28] stated that there is a strong influence of cultural and traditional aspects in Africa on livestock ownership such that in the southern highlands of Tanzania, even if a married woman signs the ownership contract or pays for a cow, the animal still belongs to the husband, and even in case of divorce, the wife cannot take the animal with her. ILRI/IDRC [29] reported that women in Kenya, Tanzania and Mozambique owned more chicken and goats and less cattle than men.

\section{Conclusion and recommendations}

Among Nupe and Yoruba in Nigeria, access to productive resources is item specific while decision making are activities specific and cannot be generalized into conventional stereotypes. The patterns observed and reported in this study show that the prevalence of the indigenous culture in family structure despite the introduction of western values. This prevalence could be attributed to low level of education and cosmopoliteness among the Nupes. The implications for extension services and development planning will include the need for gendersensitive extension methods and program as well as

Table 4 Decision making on farming activities by gender across cultures

\begin{tabular}{|c|c|c|c|c|c|c|}
\hline \multirow[t]{3}{*}{ Farming activities } & \multicolumn{3}{|l|}{ Nupe } & \multicolumn{3}{|l|}{ Yoruba } \\
\hline & \multicolumn{6}{|c|}{ Who makes decision } \\
\hline & Female & Male & No response & Female & Male & No response \\
\hline Agricultural production-subsistence & $4(8)$ & $43(86)$ & $3(6)$ & $5(10)$ & $42(84)$ & $3(6)$ \\
\hline Agricultural production-cash crop & $9(18)$ & $38(76)$ & $3(6)$ & $13(26)$ & $32(64)$ & $5(10)$ \\
\hline What inputs to buy for agricultural production & $3(6)$ & $41(82)$ & $6(12)$ & $5(10)$ & $35(70)$ & $10(20)$ \\
\hline What types of crops to grow for agricultural production & $2(4)$ & $38(76)$ & $10(20)$ & $7(14)$ & $30(60)$ & $13(26)$ \\
\hline When or who will take crops to the market & $31(62)$ & $13(26)$ & $6(12)$ & $23(46)$ & $17(34)$ & $10(20)$ \\
\hline
\end{tabular}


Table 5 Chi-square differences between gender, ownership and decision making and culture on selected productive resources among women

\begin{tabular}{lccl}
\hline & $\begin{array}{l}\text { Chi- } \\
\text { Square }\end{array}$ & df & p \\
\hline Gender-land ownership-culture & 1.54 & 2 & 0.46 \\
Gender-major owner-land-culture & 8.37 & 2 & $0.02^{* *}$ \\
Gender-land selling decision-culture & 2.10 & 2 & 0.35 \\
Gender-large livestock ownership-culture & 1.14 & 2 & 0.57 \\
Gender-major owner-large livestock-culture & 8.10 & 2 & $0.01^{* *}$ \\
Gender-large livestock selling decision-culture & 3.62 & 2 & 0.16 \\
Gender-small livestock ownership-culture & 0.36 & 2 & 0.84 \\
Gender-major owner-small livestock-culture & 12.37 & 2 & $0.002^{* * *}$ \\
Gender-small livestock selling decision-culture & 4.38 & 2 & 0.11 \\
Gender-chicken ownership-culture & 0.37 & 2 & 0.84 \\
Gender-major owner-chicken-culture & 11.46 & 2 & $0.003^{* * *}$ \\
Gender-chicken selling decision-culture & 4.25 & 2 & 0.12 \\
Gender-farm equipment ownership-culture & 2.06 & 2 & 0.36 \\
Gender-major owner-farm equipment-culture & 5.39 & 2 & $0.07^{*}$ \\
Gender-farm equipment selling decision-culture & 3.71 & 2 & 0.16 \\
\hline
\end{tabular}

*** Significant at $1 \%$; ** significant at $5 \%$; * significant at $10 \%$

development planning focusing on women and not making gender issues as appendages to the generalized development plans. The study recommends improvement in the mainstreaming and transformation of gender issues into practical actions to improve women access and control over productive resources. More programs should be introduced to enhance women and increasing implementations of existing programs to empower women.

\section{Abbreviations}

FAO: Food and Agriculture Organisation of the United Nations; ILRI: International Livestock Research Institute; IDRC: International Development Research Centre.

\section{Authors' contributions}

$\mathrm{Kl}$, and TT supervised the design, the entire data collection process and provided guide, corrections and supervision to the entire research. AAA and $\mathrm{OIO}$ designed the data collection instruments gathered the data. Analysis and write-up done by AAA, TT and OIO. All authors read and approved the final manuscript.

\section{Author details}

'Graduate School of Agriculture, Faculty of Agriculture, Kinki University, Higashiosaka, Japan. ${ }^{2}$ Department of Agricultural Economics and Extension, Mafikeng Campus, North-West University, Private Bag X 2046, Mmabatho 2735, South Africa.

\section{Acknowledgements}

None.

\section{Competing interests}

The authors declared that they have no competing interests.

Received: 27 October 2015 Accepted: 30 November 2015 Published online: 23 December 2015

\section{References}

1. Mucavele S, MuGeDe. The role of rural women in agriculture-women, gender and development, republic of Mozambique-Southern Africa Women Farmers Organisation. 2015. http://www.wfo-omacom/womenin-agriculture/articles/the-role-of-rural-women-in-agriculturehtml. Acsessed 27 Aug 2015.

2. Matthews-Njoku EC, Nwaogwugwu ON. Cultural factors affecting livelihood strategies of rural households in Southeast Nigeria: implication for agricultural transformation agenda. Russ J Agric Soc. 2014;36(3):18-26.

3. Soetan RO. Culture, gender and development a report submitted to the African Institute for Economic Development and Planning (IDEP), Senegal. Ile-Ife, Nigeria: The Centre for Gender and Social Policy Studies, Obafemi Awolowo University; 2001. p. 42-55.

4. Ogwumike FO. Current state of knowledge on poverty in Nigeria. In: Afonja S, Adelekan D, Soetan F, Alimi T, Ayanwale B, editors. Research and policy directions on poverty in Nigeria. Nigeria: Centre for Gender and Social Policy Studies; 2001. p. 24-34.

5. OECD. Gender equality in education, employment and entrepreneurship. Report on the gender initiative: Meeting of the OECD Council at Ministerial Level Paris. 25-26. May 2011. http://www.oecd.org/education/48111145.pdf. 2011.

6. Quisumbing AR, Payongayong E, Aidoo JB, Otsuka K. Women's land rights in the transition to individualized ownership: implications for tree resource management in Western Ghana. Econ Dev Cult Change. 2001;50(1):157-82.

7. Adekanye TO. Women and rural poverty: some considerations from Nigeria. Afr Notes Spec Issue. 1988;3:63-7.

8. Damisa MA, Yohanna M. Role of rural women in farm management decision making process: ordered probit analysis. Trends Appl Sci Res. 2007;2:241-5.

9. Patricia P. Technology gender and power in Africa. Ottawa: IDRC; 1989

10. Thamaga-Chitja JM, Morojele P. The context of smallholder farming in South Africa: towards a livelihood asset building framework. J Hum Ecol. 2014;45(2):147-55.

11. Oladele OI. Multilinguality of farm broadcast and agricultural information access in Nigeria. Nord J Afr Stud. 2006;15:199-205.

12. Mohammad IB, Said I. Behavioural use of courtyard in a Nupe cultural landscape of Nigeria. In: Gaol FL, editor. Research and policy directions on poverty in Nigeria. 2015. p. 227.

13. Ekong EE. An introduction to rural sociology. 2nd ed. Uyo: Dove Educational Publishers; 2003.

14. Hirose S, Wakatsuki T. Restoration of Inland Valley ecosystem in West Africa. Tokyo, Japan: Association of agriculture and forestry statistics; 2002.

15. Valdivia C, Gilles J. Gender and resource management: households and groups strategies and transitions. Agric Human Values. 2001;18(1):5-9.

16. Okonya JS, Kroschel J. Gender differences in access and use of selected productive resources among sweet potato farmers in Uganda. Agric Food Secur. 2014;3:1.

17. World Bank. Nigeria women in agriculture. Chapter II. The World Bank participation sourcebook. Environmental sustainable development series. 1818 H Street N W Washington DC 20433 USA: The World Bank; 1996: 89-94.

18. World Bank. Engendering development through gender equality in rights, resources and voice. Washington, DC and London: World Bank and Oxford University Press; 2001.

19. Parveen S. Access of rural women to productive resources in Bangladesh: a pillar for promoting their empowerment. Int J Rural Stud. 2008;15(1):1-8.

20. Ogato GS, Boon EK, Subramani J. Improving access to productive resources and agricultural services through gender empowerment: a case study of three rural communities in ambo district. Ethiopia J Hum Ecol. 2009;27(2):85-100.

21. Allendorf K. Do women's land rights promote empowerment and child health in Nepal? World Dev. 2007;35(11):1975-88.

22. Sims B, Röttger A, Mkomwa S. FAO. Hire services by farmers for farmers FAO Diversification booklet 19. Rural Infrastructure and Agro-Industries Division, Food and Agriculture Organization of the United Nations Rome 2011. 2011.

23. FAO. Gender differences in assets Prepared by the SOFA Team ESA Working Paper No. 11-12 March 2011. Agricultural Development Economics Division Food and Agriculture Organization of the United Nations 
wwwfaoorg/economic/esa. 2011, FAO. The state of Food and Agriculture: Lessons from the Past 50 years. FAO Agriculturalseries No32pp329 http:// www.fao.org/docrep/017/×4400e/×440e.pdf Accessed August, 2015 2000, IFAD. Enabling poor rural people to overcome poverty in Nigeria. Rome 1-8 http://ifad.org/operations/projects/regions/PA/factsheets/ ng.pdf Accessed August, 2015. 2012.

24. Jeiyol EN, Akpan SB, Terver NT. Gender analysis of access to credit by rural small scale farmers in benue state, Nigeria. Am Int J Soc Sci. 2013;2(6):70-8.

25. National Population Commission (NPC). 2006 population and housing census, priority table volume IX, population distribution by sex and classsize of household. Abuja: NPC; 2010. p. 291.

26. Hargreaves $\mathrm{S}$. As mining steals the basis for survival, peasant women show a way out of the crisis. In women and land rights: questions of access, ownership and control. Perspectives political analysis and commentary from Africa Heinrich Böll Foundation Africa No 213; 2010. p 19-22.

27. Fafchamps M, Quisumbing A. Marriage, bequest and assortative matching in rural Ethiopia. Econ Dev Cult Change. 2005;53(2):347-80.
28. Oluka J, Owoyesigire B, Esenu B, Ssewannyana E. Small stock and women in livestock production in the Teso farming system region of Uganda. In: small stock in development: Proceedings of a workshop on enhancing the contribution of small livestock to the livelihoods of resource-poor communities. Masaka: Hotel Brovad; 15-19 November 2004; 2005.

29. Swiss Agency for Development and Cooperation. Livestock and gender a winning pair. Working document. Bern: September 2000. 2000.

30. Women, Livestock Ownership and Markets: Bridging the gender gap in Eastern and Southern Africa. Njuki J, Sanginga PC, editors. International Livestock Research Institute and the International Development Research Centre. 2013.

31. Adereti FO. Rural women's access to and control over productive resources: implications for poverty alleviation among osun-state rural women Nigeria. J Human Ecol. 2005;18(3):225-30.

32. Ibrahim HI, Ibrahim HY. Access of rural women to productive resources in a rural area of northern Nigeria. Elixir Soc Sci. 2012;44(2012):7088-92.

\section{Submit your next manuscript to BioMed Central and we will help you at every step:}

- We accept pre-submission inquiries

- Our selector tool helps you to find the most relevant journal

- We provide round the clock customer support

- Convenient online submission

- Thorough peer review

- Inclusion in PubMed and all major indexing services

- Maximum visibility for your research

Submit your manuscript at www.biomedcentral.com/submit
(O) BioMed Central 